\title{
Effects and Profitability of Land Consolidation Projects: Case Study - the Republic of Serbia
}

\author{
Jelena LAZIĆ, Goran MARINKOVIĆ*, Mirko BORISOV, Milan TRIFKOVIĆ, llija GRGIĆ
}

\begin{abstract}
An analysis of profitability and effects of land consolidation (LC) projects has been made in this paper. The measurable effects of land consolidation resulting from land consolidation goals such as: increase of average area of parcel, decrease of average number of parcels per participant as well as the change in the area of road and canal networks after the land consolidation projects were considered. Profitability was analysed from the aspect of return on investments and net present value of investment in land consolidation. Materials and methods for this study encompass a representative sample from Vojvodina, a part of the Republic of Serbia which is flatland and predominately orientated to agricultural production. The study results indicate that the effects of land consolidation are good and that land consolidation projects are highly profitable.
\end{abstract}

Keywords: agricultural production; land consolidation; net present value; profitability

\section{INTRODUCTION}

The land consolidation is a planned process through which the arrangement of land parcels and ownership over them is performed [1]. Land consolidation is also defined as a process through which the small parcels are integrated and form continuous and centralized land in areas where the agricultural land is not utilized efficiently [2]. According to [3] implementation of land consolidation, it is conditioned with structure of land ownership, no matter whether the land belongs to individuals or corporations, and also legal documentation and elaborates.

Land consolidation is of essential importance for provision of economical sustainability for rural areas; it makes the environment management easier and rationalization of urban growth [4-6]. According to some authors [7-11], land consolidation is an important approach to sustainable development, and has been developed, from original goal to increase agricultural land to important tool for comprehensive management and development of urban and rural areas. According to [12, 13], land consolidation is proven as an efficient tool in creating better conditions for living in rural and urban areas as well as for improving sustainable utilization of agriculture and is defined as an instrument for rural development and development of contemporary agriculture. Land consolidation projects are very complex and are mostly connected with arrangement of agricultural land, building of irrigation systems, reconstruction and building of roads for agricultural purposes, design and establishment of shelterbelts and other projects for the purpose of complete arrangement of certain areas. Consequently, land consolidation is the base for complex infrastructural projects [14], mostly through provision of agricultural land and prevention of further real estate fragmentation.

The need for land consolidation has been increasing all over the world. According to [15], in China in the period from 2011 to 2015, the investment in land consolidation projects exceeded 550 billion $\$$ encompassing $35,33 \times 10^{6}$ hectares of agricultural land. In Czech Republic, from 2002 approximately a hundred of land consolidation projects were finished per year [16]. In Turkey, for example, from 1961 to 2002 , only approximately $450 \times 10^{3}$ hectares of fragmented agricultural land were land consolidated, while from 2002 to $2013,5 \times 10^{6}$ hectares of fragmented agricultural land was involved in land consolidation process [17]. These figures indicate that interest and need for land consolidation increase continuously and in many countries significance and benefits of land consolidation were recognised.

A review of contemporary definition of land consolidation and a comprehensive review of land consolidation projects clearly show that they are of high level of complexity and high financial investments and consequently designing of land consolidation should be provided carefully in order to reach the necessary level of their effects. Also, farmers and land owners find their interests in active participation in land consolidation projects through clear definitions of their specific requirements and desires, which additionally increases the complexity of land consolidation projects. In accordance with the goals of land consolidation, time required and high financial investments, it is of high importance to provide an analysis of measurable parameters that will occur after its realization. Also, bearing in mind that the economic effect is one of the most dominant reasons for provision of land consolidation it follows that they should be analysed from a financial point of view.

Some authors [18-20] state that importance of land consolidation could be specified and viewed from different perspectives. In this paper there are two aspects of viewing land consolidation effects. The first aspect is related to the structure of land ownership obtained by land consolidation. The second one is related to financial effect, i.e. profitability of land consolidation projects. The connection between profitability and land consolidation is recognized in literature. According to [21]:

- The fragmented patterns of land ownership and land use reduce profitability of agricultural production.

- Better access to roads and commune centres may increase profitability of agricultural production.

- Decrease of profitability in agricultural production provides a powerful motive for many farmers to search for other non-farm livelihood opportunities, resulting in abandonment of cultivation on less fertile and accessible parcels. 
Considering aforementioned data, it follows that land consolidation increases profitability of agricultural production, and that land consolidation should also be treated as an investment.

Starting from the assumption that the basic goal of rural development is preservation and improvement of land resources and considering the land consolidation definition it follows that land consolidation is the powerful tool for realization of the goal concerned.

Land consolidation in the Republic of Serbia has a long time tradition and it is mostly provided in Vojvodina (about $60 \%$ ), the central part of Serbia (about 9\%) and Kosovo and Metohija (about 5\%). Land consolidation in the Republic of Serbia was conducted till 2011 in 897 cadastral municipalities on the total area greater than $1,8 \times 10^{6}$ hectares, which is about $25 \%$ of total arable land. According to research conducted in the Republic of Serbia, only the farmlands with the size of property greater than 10 hectares could be the basic carriers of modern market agricultural production in rural areas [22, 23]. The participants in land consolidation are released from financing of land consolidation projects. The expenses are covered by the Republic of Serbia in the amount of 55\% and local municipalities cover it in the amount of $45 \%$.

The land consolidation projects initiation in the developed European countries such as Finland, Sweden, Netherland, Switzerland, Germany and others are conditioned by provision of the cost benefit analysis, and the benefits must be greater than the costs [24, 25].

There is no common methodology for land consolidation effects accepted [5]. The methodology varies from a country to a counter because of the differences in natural and social conditions, different goals of land politics and in most cases it is dependent on available data [26]. Bearing in mind that the wide spectra of methodologies for effects of land consolidation estimation, the chosen method should be harmonized with specific requirements in the country where the land consolidation project is provided [25].

Effects of land consolidation are analysed in different ways in literature. For example, the paper [1] presented the results of research of land consolidation effects on ecological relation and the value of ecosystem in China, while the paper [7] stressed the land consolidation as a tool for improvement of land productivity and possibly the total factor productivity if it induces and enhances technical progress. The study [25] analysed how land consolidation improves the structure of land ownership and decreases agricultural costs, as well as if obtained benefits overcome the costs in Finland. In the paper [27] the model for estimation of land consolidation influence on agricultural production is given.

In the study [28] the changes arising from implementation of land consolidation projects and the parametric approach were developed for an estimation of effects of resource environment. Other authors [29, 30] conclude that land consolidation has positive effects on the number and size of parcels, area occupied by different nonagricultural utilizations of agricultural land and rehabilitation of erosion consequences.

According to $[12,31,32]$ the positive effects of land consolidation results can be seen in improved structure of land property in rural areas, improved economics and efficiency of agricultural land utilization, improvement of agricultural production and increase of population in rural areas.

The criteria for an estimation of land consolidation effects [26] are defined (in Check Republic) on the base of size, the shape and comparison of parcels, natural and social conditions and economic benefits.

Assessments of land consolidation effects are provided in many European countries, commonly by comparing the areas in which the land consolidation was provided with the areas where it was not. In the Republic of Serbia, despite the presence of land consolidation for many decades, which is currently provided and confirmed by many land consolidation projects, till now there was no research provided about the gains and effects of land consolidation. This is the very reason for the subject of this paper to analyse the effects realized by land consolidation projects as well as their profitability as one of the most important drivers for their implementation.

The basic aims of this paper are to determine the influence of land consolidation on agricultural production and find if the land consolidation projects are profitable in the Republic of Serbia. Based on those aims, this research is divided into two parts. The first part is related to effects resulting from the aims of land consolidation, i.e. influence of land consolidation on the structure of land ownership. This part of research is conducted on the basis of the following questions:

1. How much was the parcels' size increased on average in percentage $(\%)$ ?

2. How much was the number of parcels decreased per participant in land consolidation process in percentage $(\%)$ ?

3. How much has the area under roads been changed in land consolidation process in percentage $(\%)$ ?

4. How much has the area under channels changed in land consolidation process in percentage $(\%)$ ?

The second part is related to profitability of land consolidation, i.e. to determination of the relation between benefits and costs. This part of the research is based on the following questions:

1. What is the profitability of land consolidation projects?

2. How long is the period of time for return on investment of land consolidation projects?

3 . What is net present value of land consolidation project effect?

\section{MATERIALS AND METHODS \\ 2.1 Materials}

In order to provide the starting data with the aim to analyse effects of land consolidation it is necessary to conduct an analysis of realized projects in order to obtain the real information about their effects. Based on this analysis it is possible to determine the effects of land consolidation and the estimation of its influence on agricultural production. This data will be the basis for further analysis. The material for this case study encompasses a sample of twelve realized land consolidation projects chosen in such a way that they cover all parts of Vojvodina (Srem, Banat and Bačka) (Fig. 1.) and could be considered as representative. 


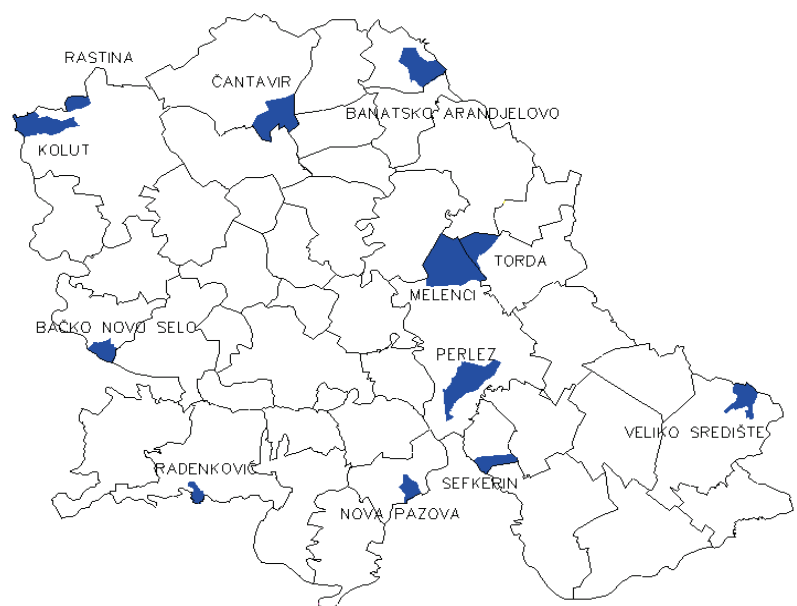

Figure 1 Position of considered land consolidation projects inside the region of Vojvodina

The data about the cadastral municipalities are gathered from the official sources of local self-government units and the official sources of the Republic Geodetic Authority of Serbia. In 2017 all the data were gathered from the official persons who were included in land consolidation activities. The obtained data include detailed official information specified in such a way that they describe areas of cadastral municipality, number of participants in land consolidation, number of parcels on the land consolidated area, areas of agricultural land and other data relevant for the research.

Table 1 The Changes of Road and Canal Network Areas

\begin{tabular}{|c|c|c|c|c|c|c|}
\hline \multirow[b]{3}{*}{ Project } & \multicolumn{3}{|c|}{ Road Network } & \multicolumn{3}{|c|}{ Canal Network } \\
\hline & \multicolumn{2}{|c|}{ Area / ha } & \multirow{2}{*}{ 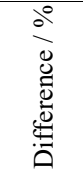 } & \multicolumn{2}{|c|}{ Area / ha } & \multirow{2}{*}{ 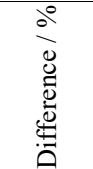 } \\
\hline & 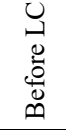 & 亗 & & 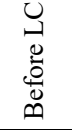 & 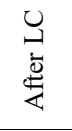 & \\
\hline Čantavir & 138 & 159 & 15,22 & 4 & 31 & 675,00 \\
\hline Perlez & 225 & 255 & 13,33 & 31 & 276 & 790,32 \\
\hline Sefkerin & 119 & 97 & $-18,49$ & 96 & 120 & 25,00 \\
\hline N. Pazova & 48 & 57 & 18,75 & 1 & 6 & 500,00 \\
\hline Rastina & 46 & 53 & 15,22 & 18 & 42 & 133,33 \\
\hline Melenci & 341 & 358 & 4,99 & 548 & 790 & 44,16 \\
\hline Kolut & 149 & 126 & $-15,44$ & 93 & 191 & 105,38 \\
\hline V. Središte & 111 & 124 & 11,71 & 46 & 84 & 82,61 \\
\hline Torda & 85 & 97 & 14,12 & 9 & 92 & 922,22 \\
\hline Aranđelovo & 179 & 157 & $-12,29$ & 158 & 218 & 37,97 \\
\hline Radenković & 11 & 34 & 209,09 & 4 & 20 & 400,00 \\
\hline Novo Selo & 42 & 54 & 28,57 & 72 & 120 & 66,67 \\
\hline Total & 1494 & 1571 & 5,15 & 1080 & 1990 & 84,26 \\
\hline
\end{tabular}

Table 2 Structure of Land Ownership - the State before and after Land Consolidation

\begin{tabular}{|c|c|c|c|c|c|c|c|c|c|c|c|}
\hline \multirow[b]{2}{*}{ Project } & \multirow[b]{2}{*}{ 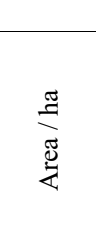 } & \multicolumn{5}{|c|}{ State before land consolidation } & \multicolumn{5}{|c|}{ State after land consolidation } \\
\hline & & 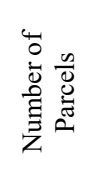 & 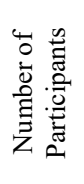 & 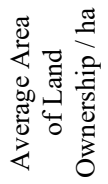 & 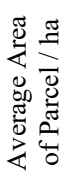 & 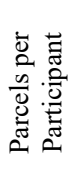 & 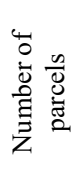 & 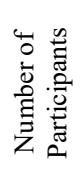 & 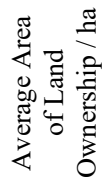 & 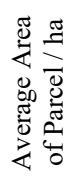 & 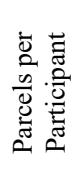 \\
\hline Čantavir & 8629 & 8533 & 3846 & 2,24 & 1,01 & 2,22 & 4525 & 3830 & 2,25 & 1,91 & 1,18 \\
\hline Perlez & 9989 & 7921 & 2147 & 4,65 & 1,26 & 3,69 & 3893 & 2448 & 4,08 & 2,57 & 1,59 \\
\hline Sefkerin & 3583 & 4061 & 1080 & 3,32 & 0,88 & 3,76 & 1994 & 949 & 3,78 & 1,80 & 2,10 \\
\hline N. Pazova & 1960 & 1159 & 710 & 2,76 & 1,69 & 1,63 & 859 & 641 & 3,06 & 2,28 & 1,34 \\
\hline Rastina & 2210 & 1433 & 366 & 6,04 & 1,54 & 3,92 & 433 & 300 & 7,37 & 5,10 & 1,44 \\
\hline Melenci & 15.338 & 17.659 & 2141 & 7,16 & 0,87 & 8,25 & 8922 & 2187 & 7,01 & 1,72 & 4,08 \\
\hline Kolut & 4178 & 5417 & 1191 & 3,51 & 0,77 & 4,55 & 1650 & 776 & 5,38 & 2,53 & 2,13 \\
\hline V.Središte & 4189 & 4025 & 1085 & 3,86 & 1,04 & 3,71 & 1355 & 978 & 4,28 & 3,09 & 1,39 \\
\hline Torda & 4537 & 6553 & 2118 & 2,14 & 0,69 & 3,09 & 3340 & 1727 & 2,63 & 1,36 & 1,93 \\
\hline Aranđelovo & 7177 & 7074 & 1501 & 4,78 & 1,01 & 4,71 & 2057 & 1011 & 7,10 & 3,49 & 2,03 \\
\hline Radenković & 1279 & 3275 & 496 & 2,58 & 0,39 & 6,60 & 1781 & 468 & 2,73 & 0,72 & 3,81 \\
\hline Novo Selo & 2990 & 2016 & 693 & 4,31 & 1,48 & 2,91 & 1152 & 694 & 4,31 & 2,60 & 1,66 \\
\hline
\end{tabular}

\begin{tabular}{|c|c|c|c|c|c|c|}
\hline Project & Area & Price / $€$ & Average & NPV & ROI & Profitability \\
\hline Čantavir & 8629 & 988.271 & 115 & 419.792 & 2,1 & 1,42 \\
\hline Perlez & 9989 & 1.149 .071 & 115 & 45.008 & 2,9 & 1,04 \\
\hline Sefkerin & 3583 & 447.085 & 125 & 60.764 & 2,6 & 1,14 \\
\hline N. Pazova & 1960 & 232.376 & 119 & -1653 & 3,0 & 0,99 \\
\hline Rastina & 2210 & 253.060 & 115 & 78.738 & 2,3 & 1,31 \\
\hline Melenci & 15.338 & 1.709 .346 & 111 & -10.107 & 3,0 & 0,99 \\
\hline Kolut & 4178 & 496.120 & 119 & 14.039 & 2,9 & 1,03 \\
\hline V. Središte & 4189 & 505.718 & 121 & 37.525 & 2,8 & 1,07 \\
\hline Torda & 4537 & 527.109 & 116 & 175.291 & 2,2 & 1,33 \\
\hline Aranđelovo & 7177 & 798.772 & 111 & 156.867 & 2,5 & 1,20 \\
\hline Radenković & 1279 & 220.623 & 172 & -62.673 & 4,3 & 0,72 \\
\hline Novo Selo & 2990 & 364.297 & 122 & -49.850 & 3,5 & 0,86 \\
\hline Average & & & 122 & 71.798 & 2,8 & 1,09 \\
\hline
\end{tabular}

The data for the research encompassed 12 realized land consolidation projects on the total area of 66059 hectares and 17374 participants before and 16009 participants after the land consolidation. The study also encompassed 69126 parcels before and 31961 parcels after the land consolidation. An average cost of realization of land consolidation projects was $122 €$ per hectare.
In Tab. 1 are the data about changes in the area of roads and canals before and after land consolidation.

Tab. 2 shows an overview of total area, number of parcels and number of sheets of immovable property, average area of parcels and average number of parcels per participant, for the state before and after the land consolidation for each cadastral municipality. 
In Tab. 3 the net present value of land consolidation, return on investment and profitability are given for each cadastral municipality.

\subsection{Methods}

The first part of the research is related to effects of land consolidation that are the consequences of land consolidation projects goals, i.e. to the effects related to improvement of land ownership structure. The gathered data are processed according to the standard statistical methods. The second part of research is related to the profitability of land consolidation projects and is based on determination of return on investments and the net present value.

The total profitability is an aggregate parameter indicating the total economic effects of land consolidation on the considered area. The increase of profitability of agricultural production is of the informative character for investors and implicates justification of investment in agricultural production but it does not give the precise information about financial effects of land consolidation indicating the relation between investment and return on investment in a certain period of time.

The profitability of agricultural production related to land consolidation could be obtained by the formula [33]:

$R_{\mathrm{pp}}=n \frac{\Delta P_{\mathrm{r}}}{T_{\mathrm{k}}}$

where $R_{\mathrm{pp}}$ - increase of profitability of agricultural production because of land consolidation, $n$-number of years of exploitation of land consolidation contribution to agricultural production, $\Delta P_{\mathrm{r}}$ - difference in incomes after and before the land consolidation and $T_{\mathrm{k}}$ - land consolidation costs. The profitability of land consolidation appears when $R_{\mathrm{pp}}>1$.

The return on investments in years could be determined by the formula [33]:

$t=\frac{C_{\mathrm{k}}}{C}$

where $t$ - time interval in which the investments return (return on investments period), $C_{\mathrm{k}}$ - the cost of land consolidation project and $C$ - average annual financial effect of land consolidation.

For determination of the net present value of land consolidation it is necessary to introduce certain assumptions. Bearing in mind that an average period of land consolidation project in Serbia is 3 years, it could be assumed that the costs will be divided in this period of time. To calculate investment the rate of capitalisation is determined by investor itself [25]. In the land consolidation projects in Serbia the utilized rate of capitalisation is $3 \%$. This value is adopted because it is the rate for government bonds. The utilization of this value provides comparability of analysis [25].

\section{RESULTS}

The first part of research is related to the analysis of effects that are the consequence of land consolidation goals. On the basis of the data given in Tab. 2 and using standard statistical methods the average increment of a parcel's size is determined (results are given in Tab. 4) as well as the decrease of average number of parcels per participant in a land consolidation project (results are given in Tab. 5) in percentage (\%).

Table 4 The Increment of Average Area of Parcel

\begin{tabular}{|l|c|c|c|c|}
\hline \multirow{2}{*}{ Project } & \multicolumn{2}{|c|}{ Average area of parcel } & \multicolumn{2}{c|}{ Difference } \\
\cline { 2 - 5 } & Before LC & After LC & $/$ ha & $/ \%$ \\
\hline Čantavir & 1,01 & 1,91 & 0,90 & 89,11 \\
\hline Perlez & 1,26 & 2,57 & 1,31 & 103,97 \\
\hline Sefkerin & 0,88 & 1,80 & 0,92 & 104,55 \\
\hline N. Pazova & 1,69 & 2,28 & 0,59 & 34,91 \\
\hline Rastina & 1,54 & 5,10 & 3,56 & 231,17 \\
\hline Melenci & 0,87 & 1,72 & 0,85 & 97,70 \\
\hline Kolut & 0,77 & 2,53 & 1,76 & 228,57 \\
\hline V. Sretište & 1,04 & 3,09 & 2,05 & 197,12 \\
\hline BačkiBreg & 0,42 & 2,00 & 1,58 & 376,19 \\
\hline Torda & 0,69 & 1,36 & 0,67 & 97,10 \\
\hline Aranđelovo & 1,01 & 3,49 & 2,48 & 245,54 \\
\hline Average & & & 1,52 & 164,18 \\
\hline
\end{tabular}

Table 5 The Decrease of Average Number of Parcels per Participant

\begin{tabular}{|l|c|c|c|c|}
\hline \multirow{2}{*}{\multicolumn{1}{c|}{ Project }} & $\begin{array}{c}\text { Number of parcels per } \\
\text { participant }\end{array}$ & \multicolumn{2}{c|}{ Difference } \\
\cline { 2 - 5 } & Before LC & After LC & $/$ ha & $/ \%$ \\
\hline Čantavir & 2,22 & 1,18 & $-1,04$ & $-46,85$ \\
\hline Perlez & 3,69 & 1,59 & $-2,10$ & $-56,91$ \\
\hline Sefkerin & 3,76 & 2,10 & $-1,66$ & $-44,15$ \\
\hline N. Pazova & 1,63 & 1,34 & $-0,29$ & $-17,79$ \\
\hline Rastina & 3,92 & 1,44 & $-2,48$ & $-63,27$ \\
\hline Melenci & 8,25 & 4,08 & $-4,17$ & $-50,55$ \\
\hline Kolut & 4,55 & 2,13 & $-2,42$ & $-53,19$ \\
\hline V. Središte & 3,71 & 1,39 & $-2,32$ & $-62,53$ \\
\hline Torda & 3,09 & 1,93 & $-1,16$ & $-37,54$ \\
\hline Aranđelovo & 4,71 & 2,03 & $-2,68$ & $-56,90$ \\
\hline Radenković & 6,60 & 3,81 & $-2,79$ & $-42,27$ \\
\hline Novo Selo & 2,91 & 1,66 & $-1,25$ & $-42,96$ \\
\hline Average & & & $-2,03$ & $-47,91$ \\
\hline
\end{tabular}

An analysis of data given in Tab. 1, Tab. 4 and Tab. 5 indicates that land consolidation projects realized in the Republic of Serbia resulted in an increase of average area of parcels in the amount of $132,50 \%$ and a decrease of number of parcels per participant in the amount of $47,91 \%$. The areas under roads and canal networks increased by $5,15 \%$ and $84,26 \%$, respectively.

The second part of the research relates to an analysis of financial effects of land consolidation. The profitability of land consolidation projects expressed through return on investments and net present values is as follows (Tab. 3):

- the profitability of land consolidation projects on the basis of 3 years is $R_{\mathrm{pp}}=1,09$,

- $\quad$ the average return on investment is 2,8 years, and

- the average net present value based on three-year period is $71798 €$ per land consolidation project.

\section{DISCUSSION}

The research provided in this work gives a detailed analysis of land consolidation effects and profitability based on 12 representative projects in the Republic of Serbia. The results indicate that significant effects based on land consolidation goals were achieved. The results also 
indicate that land consolidation projects were highly profitable. The land ownership size, number of parcels per owner and area under road and canal networks are the basic elements defining the structural quality of land ownership. According to the provided analysis of available data related to the average size of parcels it may be concluded that an increase of average size of parcels after the land consolidation was $132,50 \%$. Bearing in mind that it was the result of representative land consolidation projects those values could be considered an average increase for the territory of Vojvodina.

Comparing the results in this paper with the Finish ones where the increase is $106,17 \%$ [25] and with the Chinese where the increase is $175,95 \%$ [28], it might be concluded that the obtained results are significantly higher than in Finland and slightly lower than in China. It should be noted that the results in Finland are based on 12 projects and in China the results are based on one project only.

An analysis of the decrease of the number of parcels per participant after the land consolidation indicates that the number of parcels was decreased by $47,91 \%$ on average, which could also be considered an average for the territory of Vojvodina. Comparing the reduction of the number of parcels per participant after the land consolidation with results for Finland where the reduction was 50,30\% [25] and with results for China where the reduction was $53,66 \%$ [28], it might be concluded that the results are almost equal. Bearing in mind that farmland fragmentation may reduce the yield of agricultural production by up to $9,8 \%$ and reduction of number of plots from 4 to 1 in the sample increases the total productivity factor by $8 \%$ [34], it follows that land defragmentation achieved by land consolidation in Serbia justifies investments.

On the basis of data analysis related to the changes of the area under roads networks after the land consolidation, it follows that in some cadastral municipalities there was an increase and in some of them there was a decrease after the land consolidation. The reason might be that in some cadastral municipalities there are too many roads and some of them were out of optimal functionality. This was corrected by the land consolidation projects and the area under roads was decreased but functionality of road network was increased. The increase of area under road network was a consequence of lack of roads in some cadastral municipalities and land consolidation projects corrected this problem. An increase of area under road network after the land consolidation is $5,15 \%$ on average, which could be considered an average for Vojvodina.

An analysis of data describing an increase of area under canal network after the land consolidation shows that the average increase is $84,26 \%$, which is a significant increment with potential of positive effects on agricultural production.

The time period of 3 years used for profitability analysis of land consolidation projects could be considered a strict criterion. According to the results shown in Tab. 3 it is possible to conclude that the coefficient of agricultural profitability influenced by land consolidation projects in the Republic of Serbia, based on three-year period, has an average value of 1,09 , i.e. the investment in land consolidation projects is profitable in the period of 3 years. Only four cadastral municipalities have coefficient of profitability less than 1 , while in rest of the cases this coefficient is greater than 1. Bearing in mind that the period of 3 years is extremely short it is possible to conclude that the obtained results are highly acceptable for investors.

It is necessary to highlight the fact that this analysis does not include the parameters which, because of land consolidation, additionally increase profitability of agricultural production and might shorten the period for return on investment obtained by the utilized model. It means that effects of land consolidation may only shorten the period of return on investments related to the period obtained in this paper. The values for calculation are obtained on the basis of data of grain from the product market in Novi Sad of $0,14 € / \mathrm{kg}$ and average yields of 3200 $\mathrm{kg} / \mathrm{ha}$ (on 16 August 2017).

The return on investment for investment in land consolidation, in case of real scenario, lasts between 2,1 and 4,3 years for the Republic of Serbia (Vojvodina). If the effects of increased infrastructure potential are taken into account, which could be at the level of $20 \%$ (i.e. in case of optimistic scenario) the return on investment could be shorter. The calculated average of net present value per land consolidation project is $71798 €$. In 8 projects the net present values are positive, while in 4 projects the net present values are negative. Bearing in mind the strictness of criteria (only 3 years for calculation of net present value) the obtained result could be treated as acceptable.

After the land arrangement in the Republic of Serbia the differences in agricultural production were noticed and it is realistic to expect them also after the realization of land consolidation projects in the future. The significant changes appeared after land arrangement in the conditions related to agricultural production that are connected to water and air regime in land as well as in the structure of land ownership (increase of parcels, their distribution and size). Those changes generate better chances to maximize the potential of land for agricultural production including utilization of contemporary agricultural mechanization.

Financial effects of land consolidation provide the return on investment in period of approximately 3 years, indicating high rate of land consolidation projects profitability. If the long term profitability (because the positive effects of land consolidation last much longer than 3 years) and indirect benefits of land consolidation are taken into account, it follows that profitability of land consolidation is greater than the results obtained by the model proposed in this paper. Additional values obtained by land consolidation that could not be expressed in financial terms or could not be measured easily but proven in practice (such as: increase of legal regulation of land ownership, decrease of potential damages by creating conditions for efficient building of adequate hydro technical and road structures, establishment of geodetic networks, optimization of costs for agricultural production and other benefits) also increase the value of cadastral municipalities.

\section{CONCLUSION}

This research proved that direct effects of land consolidation as well as direct financial effects justify the land consolidation in the Republic of Serbia while the following effects, even though they could not be easily 
measured or measured at all, additionally increase the value of agricultural land in the cadastral municipalities where the land consolidation is provided.

According to the conducted analysis and proposed methodology for estimation of the contribution of land consolidation to improvement of agricultural production in the Republic of Serbia (Vojvodina) it is possible to conclude as follows:

- contribution of land consolidation to the agricultural production in the Republic of Serbia, even in a very conservative estimation, is significant,

- direct effects that are the consequence of land consolidation goals are significant especially in the domain of reduction of number of parcels per participant and increase of average area of parcel after the land consolidation, which significantly improves utilization of contemporary agricultural mechanization,

- economic effects of land consolidation are only one dimension of its contribution to uniform development of the Republic of Serbia because it could also have, along with economic, effects of increase of quality of living in rural areas and reduction of migrations from rural areas,

- $\quad$ solution of property relations in rural areas also has positive effects for efficient management of land,

- low price of land consolidation per hectare in the Republic of Serbia should be treated as a chance because in European countries this price is significantly higher, and

- $\quad$ return on investment measured by contribution of land consolidation is favourable and it is about 3 years.

All analysed effects of land consolidation justify investment in land consolidation in the territory of the Republic of Serbia, because the period of return on investment in land consolidation is significantly shorter than in other countries. Additional justification for land consolidation is supported by indirect positive effects of land consolidation on decrease of land ownership fragmentation and increase of profitability of agricultural production.

\section{REFERENCES}

[1] Wang, J., Yan, S., Guo, Y., Li, J., \& Sun, G. (2015). The effects of land consolidation on the ecological connectivity based on ecosystem service value: A case study of Da'an land consolidation project in Jilin province. Journal of Geographical Sciences, 25(5), 603-616. https://doi.org/10.1007/s11442-015-1190-y

[2] Yan, J., Xia, F., \& Li, Q. (2012). Top strategy design of comprehensive land consolidation in China. Transactions of the Chinese Society of Agricultural Engineering, 28(14), 1-9 (in Chinese with English abstract)

[3] Poropat, A. (2017). Planned building land consolidation in the context of land subdivision of a unique plot.Technical Gazette, 24(3), 887-895. https://doi.org/10.17559/TV-20160630221130

[4] Van Lier, H. N. (2000). Land use planning and land consolidation in the future in Europe. Zeitschrift für Kulturtechnik und Landentwicklung, 41(3), 138-144.

[5] Crecente, R., Alvarez, C., \& Fra, U. (2002). Economic, social and environmental impact of land consolidation in Galicia. Land Use Policy, 19, 135-147.
https://doi.org/10.1016/S0264-8377(02)00006-6

[6] Ivković, M., Barković, Đ., \& Baćani, S. (2010). Komasacija zemljišta I ruralni razvoj. Geodetski list, 87(4), 297-312. Retrieved from https://hrcak.srce.hr/64686

[7] Huang, Q. H., Li, M. C., Chen, Z. J., \& Li, F. X. (2011). Land consolidation: an approach for sustainable development in rural China. AMBIO, 40(1), 93-95. https://doi.org/10.1007/s13280-010-0087-3

[8] Long, H. L. (2014). Land consolidation: an indispensable way of spatial restructuring in rural China. Journal of Geographical Sciences, 24(2), 211-225. https://doi.org/10.1007/s11442-014-1083-5

[9] Long, H. L., Li, Y., Liu, Y., Woods, M., \& Zou, J. (2012). Accelerated restructuring in rural China fuelled by 'increasing vs. decreasing balance': land-use policy for dealing with hollowed villages. Land Use Policy, 29, 11-22. https://doi.org/10.1016/j.landusepol.2011.04.003

[10] Reerink, G. \& Van Gelder, J. L. (2010). Land titling, perceived tenure security, and housing consolidation in the kampongs of Bandung, Indonesia. Habitat International, 34(1), 78-85. https://doi.org/10.1016/j.habitatint.2009.07.002

[11] Xia, F., Yan, J., \& Liu, J. (2014). Research on governance path of rural settlements reconstruction patterns. Transactions of the Chinese Society of Agricultural Engineering, 30(3), 215-222 (in Chinese with English abstract).

[12] Miranda, D., Crecente, R., \& Alvarez, M. F. (2006). Land consolidation in inland rural Galicia, N.W. Spain, since 1950: an example of the formulation and use of questions, criteria and indicators for evaluation of rural development policies. Land Use Policy, 23, 511-520. https://doi.org/10.1016/j.landusepol.2005.05.003

[13] Haldrup, N. O. (2015). Agreement based land consolidationIn perspective of new modes of governance. Land Use Policy, 46, 163-177. https://doi.org/10.1016/j.landusepol.2015.01.027

[14] Hendricks, A. \& Lisec, A. (2014). Land consolidation for large-scale infrastructure projects in Germany. Geodetski vestnik, 58(1), 46-68. https://doi.org/10.15292/geodetski-vestnik.2014.01.046-068

[15] Yan, J., Shen, Y., \& Xia, F. (2017). Differentiated Optimization of Sustainable Land Use in Metropolitan Areas: A Demarcation of Functional Units for Land Consolidation. Sustainability, 9(8), 1356. https://doi.org/10.3390/su9081356

[16] Sklenicka, P., Hladík, J., Střeleček, F., Kottová, B., Lososová, J., Č́íhal, L., \& Šálek, M. (2009). Historical, environmental and socio-economic driving forces on land ownership fragmentation, the land consolidation effect and the project costs. Agric. Econ.-Czech, 55(12), 571-582. https://doi.org/10.17221/115/2009-AGRICECON

[17] Uyan, M. (2016). Determination of agricultural soil index using geo-statistical analysis and GIS on land consolidation projects: A case study in Konya/Turkey. Computers and Electronics in Agriculture, 123, 402-409. https://doi.org/10.1016/j.compag.2016.03.019

[18] Lisec, A., Primozič, T., Ferlan, M., Sumrada, R., \& Drobne, S. (2014). Land owners' perception of land consolidation and their satisfaction with the results-Slovenian experiences. Land Use Policy, 38, 550-563. http://doi.org/10.1016/j.landusepol.2014.01.003

[19] Korthals, A. W. \& Bong, I.S. (2011). Promoting rural development through the use of land consolidation: the Case of Korea. Int. Plan. Stud., 16, 151-167. https://doi.org/10.1080/ 13563475.2011.561060

[20] Pražan, J. \& Dumbrovsky, M. (2010). Soil conservation policies: conditions for their effectiveness in the Czech Republic. Land Degrad. Dev., 21, 124-133. https://doi.org/10.1002/ Idr.1066 
[21] Sikor, T., Müller, D., \& Stahl, J. (2009).Land Fragmentation and Cropland Abandonment in Albania: Implications for the Roles of State and Community in Post-Socialist Land Consolidation. World Development, 37(8), 1411-1423. https://doi.org/10.1016/j.worlddev.2008.08.013

[22] Trifković, M., Marinković, G., Ilić, B., Pejičić, G., \& Lazić, J. (2016). Land consolidation and irrigation, case study Municipality of Velika Plana. Archives for Technical Sciences, 14(1), 35-45. http://doi.org/10.7251/afts.2016.0814.035T.

[23] Marinković, G., Ninkov, T., Trifković, M., Nestorović, Ž., \& Pejičić, G. (2016). On the land consolidation projects and cadastral municipalities ranking. Technical Gazette, 23(4), 1147-1153. https://doi.org/10.17559/TV-20140316225250

[24] Hiironen, J., Mattila, P., Lääti, M., Oja, H., Katajamäki, M., Tanskanen, H., Konttinen, K., \& Penttilä, L. (2010). Renewing the evaluation of land consolidation effects. FIG Congress 2010: Facing the Challenges-Building the Capacity (11. 5-16.5.2010). Sydney, Australia, 1-13.

[25] Hiironen, J. \& Riekkinen, K. (2016). Agricultural impacts and profitability of land consolidations. Land Use Policy, 55, 309-317. http://doi.org/10.1016/j.landusepol.2016.04.018

[26] Sklenicka, P. (2006). Applying evaluation criteria for the land consolidation effect to three contrasting study areas in Czech Republic. Land Use Policy, 23, 502-510. https://doi.org/10.1016/j.landusepol.2005.03.001

[27] Nestorović, Ž.,Trifković, M., Marinković, G., \& Lazić, J. (2018). Land consolidation and profitability ratios in agricultural. In Proceedings of the International Scientific Agriculture Symposium "Agrosym 2018" (04.10.-07.10. 2018). Jahorina, Bosnia and Herzegovina, 2068-2075. Retrieved from http://agrosym.ues.rs.ba/agrosym/agrosym 2018/BOOK OF PROCEEDINGS 2018 FINAL.pdf

[28] Z̄hang, Z., Zhao, W., \& Gu, X. (2014). Changes resulting from a land consolidation project (LCP) and itsresourceenvironment effects: A case study in Tianmen City of Hubei Province, China. Land Use Policy, 40, 74-82. https://doi.org/10.1016/j.landusepol.2013.09.013

[29] Bonfanti, P., Fregonese, A., \& Sigura, M. (1997). Landscape analysis in areas affected by land consolidation. Landscape and Urban Planning, 37(1-2), 91-98. https://doi.org/10.1016/S0169-2046(96)00373-8

[30] Mihara, M. (1996). Effect of agricultural land consolidation on erosion processes in semi-mountainous paddy fields of Japan. Journal of Agricultural Engineering Research, 64(3), 237-247. https://doi.org/10.1006/jaer.1996.0064

[31] Muchová, Z., Leitmanová, M., \& Petrovič, F. (2016). Possibilities of optimal land use as a consequence of lessons learned from land consolidation projects (Slovakia). Ecological Engineering, 90, 294-306. https://doi.org/10.1016/j.ecoleng.2016.01.018

[32] Tomić, H., MastelićIvić, S., \& Roić, M. (2018). Land Consolidation Suitability Ranking of Cadastral Municipalities: Information-Based Decision-Making Using Multi-Criteria Analyses of Official Registers' Data. International Journal of Geo-Information, 7(3), 87. https://doi.org/10.3390/ijgi7030087

[33] Lazić, J., Marinković, G., Trifković, M., \& Nestorović, Ž. (2018). An analysis of the profitability of land consolidation projects: Apatin case study. In Proceedings of the Contemporary Achievements in Civil Engineering, Faculty of civil engineering Subotica, 663-671. https://doi.org/10.14415/konferencijaGFS2018.065

[34] Lu, X., Xianjin, H., Taiyang, Z., Yuntai, Z., \& Yi, L. (2013). A review of farmland fragmentation in China. Journal of Resources and Ecology, 4(4), 344-353.

https://doi.org/10.5814/j.issn.1674-764x.2013.04.007

\section{Contact information:}

Jelena LAZIĆ, M.Sc., Teacher Assistant, University of Novi Sad, Faculty of Technical Sciences, Trg Dositeja Obradovića 6, 21000 Novi Sad, Serbia E-mail: lazicjelena@uns.ac.rs

Goran MARINKOVIĆ, PhD, Assistant Professor, (Corresponding author)

University of Novi Sad, Faculty of Technical Sciences Trg Dositeja Obradovića 6, 21000 Novi Sad, Serbia

E-mail: goranmarinkovic@uns.ac.rs

Mirko BORISOV, PhD, Associate Professor, University of Novi Sad, Faculty of Technical Sciences Trg Dositeja Obradovića, 6, 21000 Novi Sad, Serbia

E-mail:mborisov@uns.ac.rs

Milan TRIFKOVIĆ, PhD, Full Professor,

University of Novi Sad, Faculty of Civil Engineering,

Kozaračka Street 2a, 24000 Subotica, Serbia

E-mail: milantri@eunet.rs

Ilija GRGIĆ, PhD, Assistant Professor,

European University of Brčko District, Technical Faculty,

Bijeljinska cesta 73-74, 76100 Brčko, Bosnia and Herzegovina

E-mail: ilija66.grgic@gmail.com 